\title{
Biomarker Evidence of Relatively Stable Community Structure in the Northern South China Sea during the Last Glacial and Holocene
}

\author{
Juan $\mathrm{He}^{1}$, Meixun Zhao ${ }^{1, *}$, $\mathrm{Li} \mathrm{Li}^{1}$, Hui Wang ${ }^{1}$, and Pinxian Wang ${ }^{1}$ \\ ${ }^{1}$ Sate Key Laboratory of Marine Geology, School of Ocean and Earth Sciences, Tongji University, Shanghai, China
}

Received 13 October 2007, accepted 19 November 2007

\begin{abstract}
High-resolution molecular abundance records for several marine biomarkers during the last glacial and Holocene have been generated for core MD05-2904 (19 $27.32^{\prime} \mathrm{N}, 116^{\circ} 15.15^{\prime} \mathrm{E}, 2066 \mathrm{~m}$ water depth) from the northern South China Sea. The $\mathrm{U}_{37}^{\mathrm{K}^{\prime}} \mathrm{SST}$ record indicates a $4.4^{\circ} \mathrm{C}$ cooling during the Last Glacial Maximum for this site, consistent with previous reconstructions. The contents of $\mathrm{C}_{37}$ alkenones, dinosterol, brassicasterol, and $\mathrm{C}_{30}$ alkyl diols are used as productivity proxies for haptophytes, dinoflagellates, diatoms, and eustigmatophytes, respectively. These records reveal that both individual phytoplankton group and total productivity increased by several factors during the LGM compared with those for the Holocene, in response to increased nutrient supply. However, the community structure based on biomarker percentages remained relatively stable during the last glacial-Holocene transition, although there were short-term oscillations.
\end{abstract}

Key words: Biomarkers, Paleo-productivity, Community structure, Sea surface temperature, South China Sea

Citation: He, J., M. Zhao, L. Li, H. Wang, and P. Wang, 2008: Biomarker evidence of relatively stable community structure in the Northern South China Sea during the last glacial and Holocene. Terr. Atmos. Ocean. Sci., 19, 377-387, doi: 10.3319/TAO.2008.19.4.377(IMAGES)

\section{INTRODUCTION}

A multi-biomarker approach has been used to reconstruct both total and individual phytoplankton productivity, and thus applied to reconstruct paleo-community structure change in a variety of climate settings (Schubert et al. 1998; Hinrichs et al. 1999; Versteegh and Zonneveld 2002; Menzel et al. 2003; Schulte and Bard 2003; Higginson and Altabet 2004; Zhao et al. 2006b). Different patterns of community structure change have emerged from those reconstructions. In the Arabian Sea, the community structure was remarkably stable for $200 \mathrm{kyr}$, despite the large changes in both total and individual phytoplankton productivity (Schubert et al. 1998). But in the Cariaco Basin (Werne et al. 2000) and in the Okhotsk Sea (Seki et al. 2004), structure changes between diatom-dominated community and haptophyte-dominated community occurred during glacial to Holocene transitions. These changes could have played a role in regulating atmospheric $\mathrm{CO}_{2}$ levels over glacialinterglacial timescales (Werne et al. 2000; Higginson and Altabet 2004).

\footnotetext{
* Corresponding author

E-mail:maxzhao@mail.tongji.edu.cn
}

The South China Sea (SCS) has offered many high resolution paleoclimate records due to its relatively high sedimentation rate. So far the application of biomarkers for the SCS reconstruction is mostly based on alkenone analysis (Huang et al. 1997b; Pelejero et al. 1999a; Steinke et al. 2001; Kienast et al. 2001b, 2003; Zhao et al. 2006a). For example, the $\mathrm{U}_{37}^{\mathrm{K}^{\prime}}$ index has been used for cores from both the northern and southern SCS, and the results helped to constrain the glacial-interglacial SST differences for the SCS, which was $4-5^{\circ} \mathrm{C}$ in the northern SCS and $2-4^{\circ} \mathrm{C}$ in the southern SCS (Huang et al. 1997a, b; Pelejero et al. 1999a; Wang et al. 1999a; Steinke et al. 2001; Kienast et al. 2001b, 2003; Zhao et al. 2006a). Alkenone content records revealed that haptophyte productivity was higher during the glacial periods for the northern SCS (Huang et al. 1997b; Kienast et al. 2001a), but there was no clear glacial-interglacial pattern for the southern SCS (Kienast et al. 2001a; Zhao et al. 2006a). Other marine biomarkers have not been measured for SCS cores, so no estimates of biomarker-based community structure changes have been reported for the SCS. However, other approaches have been attempted for the SCS, which revealed some changes in community structure between glacial and interglacial for the southern SCS. The 
TOC: carbonate rain ratio was used as a community structure proxy for the southeastern SCS (Thunell et al. 1992), and the higher ratio during the glacial was suggested to reflect more siliceous phytoplankton production, such as diatoms. In contrast, the opal record from the southern SCS (ODP Site 1143) indicates lower diatom productivity during the glacials (Wang and Li 2003). For the northern SCS, most records indicate higher productivity during glacial periods, but these proxies could not offer estimates of community structure changes.

In this paper, we report new molecular content data for $\mathrm{C}_{37}$ alkenones, dinosterol, brassicasterol, and $\mathrm{C}_{30}$ alkyl diols of the last glacial and Holocene for core MD05-2904 from the northern SCS. The aim is to construct both productivity and community structure changes for this site during the last glacial to Holocene transition. Our approach is based on the assumptions that: (1) sedimentary biomarker contents can be used as proxies for phytoplankton productivity: alkenones for haptophytes, dinosterol for dinoflagellates, brassicasterol for diatoms, and alkyl diols for eustigmatophytes; (2) the total contents of these biomarkers can be used as a total productivity proxy; and (3) the biomarker content percentage can be used as a community structure proxy. The $\mathrm{C}_{37}$ alkenones are also used to generate an SST record for this core using the $\mathrm{U}_{37}^{\mathrm{K}^{\prime}}$ index. Comparison of the SST and productivity records would help to evaluate the fertilization mechanisms for different phytoplanktons.

\section{MATERIALS AND METHODS}

Core MD05-2904 (19 $27.32^{\prime} \mathrm{N}, 116^{\circ} 15.15^{\prime} \mathrm{E}, 2066 \mathrm{~m}$ water depth) was retrieved on the continental slope of the northern SCS (Fig. 1). For the top 10 meters of the core, $1-\mathrm{cm}$ interval samples were taken every $8 \mathrm{~cm}$ for biomarker analysis and 2-cm interval samples were taken every $8 \mathrm{~cm}$ for planktonic foraminiferal oxygen isotope analysis. The planktonic foraminiferal Globigerinoides ruber was picked and then ultrasonically washed in ethanol. The $\delta^{18} \mathrm{O}$ value of the foraminifers was measured on a Finnigan MAT 252 mass spectrometer equipped with the Kiel automatic carbonate device with an instrumental error of $\pm 0.07 \%$. However, since there are large morphotypic $\delta^{18} \mathrm{O}$ variations (Steinke et al. 2005) and we did not distinguish morphyotypes (s.s. and s.l.) in picking G. ruber, our $\delta^{18} \mathrm{O}$ record can have uncertainty as large as $0.4 \%$.

For lipid analysis, sub-samples were freeze-dried and manually ground. After adding internal standards, $\sim 2$-g samples were extracted by a mixture of dichloromethane/ methanol (3:1, V/V) ultrasonically several times. The extracts were dried and then saponified with $6 \% \mathrm{KOH} /$ methanol over night. Neutral components containing the biomarkers for this study were extracted with $n$-hexane, and they were further separated into two sub-fractions using a silica gel column. After concentration, the second fraction containing the alkenones, sterols and diols was derivatized with N,O-bis(trimethylsily)-trifluoroacetamide (BSTFA), and analyzed by gas chromatography (GC).

GC analysis was performed on a Trace GC 2000 (Finnigan, Thermo Electron) equipped with a splitless injector, a flame ionization detector and on an HP-1 capillary column $(50 \mathrm{~m} \times 0.32 \mu \mathrm{m} \times 0.17 \mu \mathrm{m})$. Both the injector and the detector were set at $280^{\circ} \mathrm{C}$. Helium was used as the carrier gas with a flow rate of $1.2 \mathrm{ml} \mathrm{min}^{-1}$. The oven was kept initially at $60^{\circ} \mathrm{C}$ for $1 \mathrm{~min}$, then programmed from $60^{\circ} \mathrm{C}$ to $200^{\circ} \mathrm{C}$ at $15^{\circ} \mathrm{C} \mathrm{min}^{-1}$, followed successively by $5^{\circ} \mathrm{C} \mathrm{min}^{-1}$ to $270^{\circ} \mathrm{C}, 2^{\circ} \mathrm{C} \mathrm{min}^{-1}$ to $300^{\circ} \mathrm{C}$ (maintained for $22 \mathrm{~min}$ ), and $5^{\circ} \mathrm{C} \min ^{-1}$ to $310^{\circ} \mathrm{C}$. Selected samples were analyzed by GC-MS (Trace DSQ) for compound identification, using the same GC conditions. The contents of the biomarkers were calculated by comparing their peak areas with that of the internal standard $\left(\mathrm{C}_{36} n\right.$-alkane), and this method has relatively large errors up to $10 \%$. However, the biomarker ratios can be calculated without using the internal standard, which resulted in errors less than $3 \%$.

\section{RESULTS AND DISCUSSION}

\subsection{Oxygen Isotope Record}

$\delta^{18} \mathrm{O}$ record for the planktonic foraminifera Globigerinoides ruber of core MD05-2904 is shown in Fig. 2b. It has a

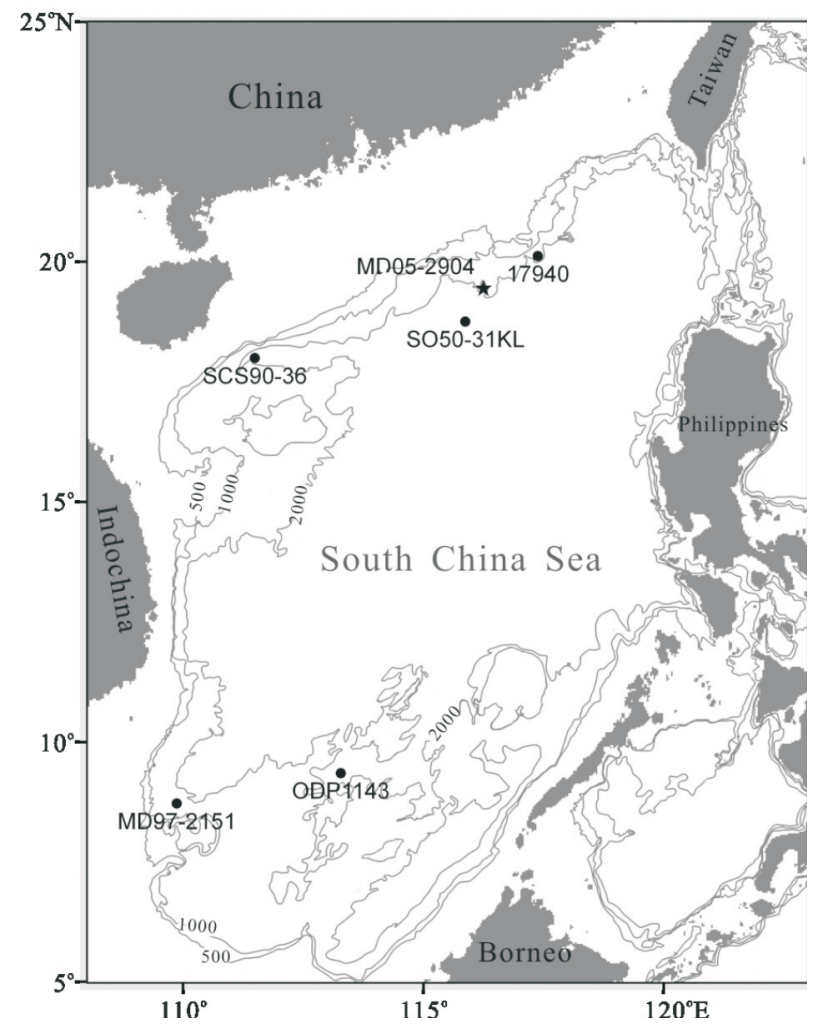

Fig. 1. Physiographic map of the South China Sea and location of core MD05-2904 ( $\star$ ). The locations of several other cores $(\bullet)$ mentioned in the text are also shown here for comparison. 
range between $-1 \%$ and $-3 \%$. Heavier $\delta^{18} \mathrm{O}$ values of ca. $-1 \%$ were recorded in several intervals between 980 and $520 \mathrm{~cm} . \delta^{18} \mathrm{O}$ value showed an upward decrease around $520 \mathrm{~cm}$ and reached a light value of $-2.78 \%$ at $258 \mathrm{~cm}$. Since no ${ }^{14} \mathrm{C}$ dates have been obtained for this core, we have established a tentative age model by correlating the $\delta^{18} \mathrm{O}$ record of this core with that of 17940 (Fig. 2d), a nearby core which has many ${ }^{14} \mathrm{C}$ dates (Wang et al. 1999a). The two $\delta^{18} \mathrm{O}$ records show good correlation, which provides some support for our age model. Based on this age model, the beginning of our record $(1000 \mathrm{~cm})$ is approximately $35 \mathrm{ka}$. Although this preliminary age model needs confirmation and improvement by ${ }^{14} \mathrm{C}$ dating, it allows us to broadly define and divide the SST (Fig. 2a) as well as other molecular records (Figs. 3, 5) into four intervals for the following discussion. The preLGM (Last Glacial Maximum) interval is between 1000 and $760 \mathrm{~cm}$, the LGM between 760 and $520 \mathrm{~cm}$, the deglaciation period between 520 and $260 \mathrm{~cm}$, and the Holocene in the top $260 \mathrm{~cm}$ (Fig. 2). Thus, the glacial-Holocene $\delta^{18} \mathrm{O}$ difference is about $2 \%$. The $\delta^{18} \mathrm{O}$ record is characterized by many oscillations on the order of 0.5 to $1 \%$ for the whole interval, and the amplitude is slightly larger for the Holocene than

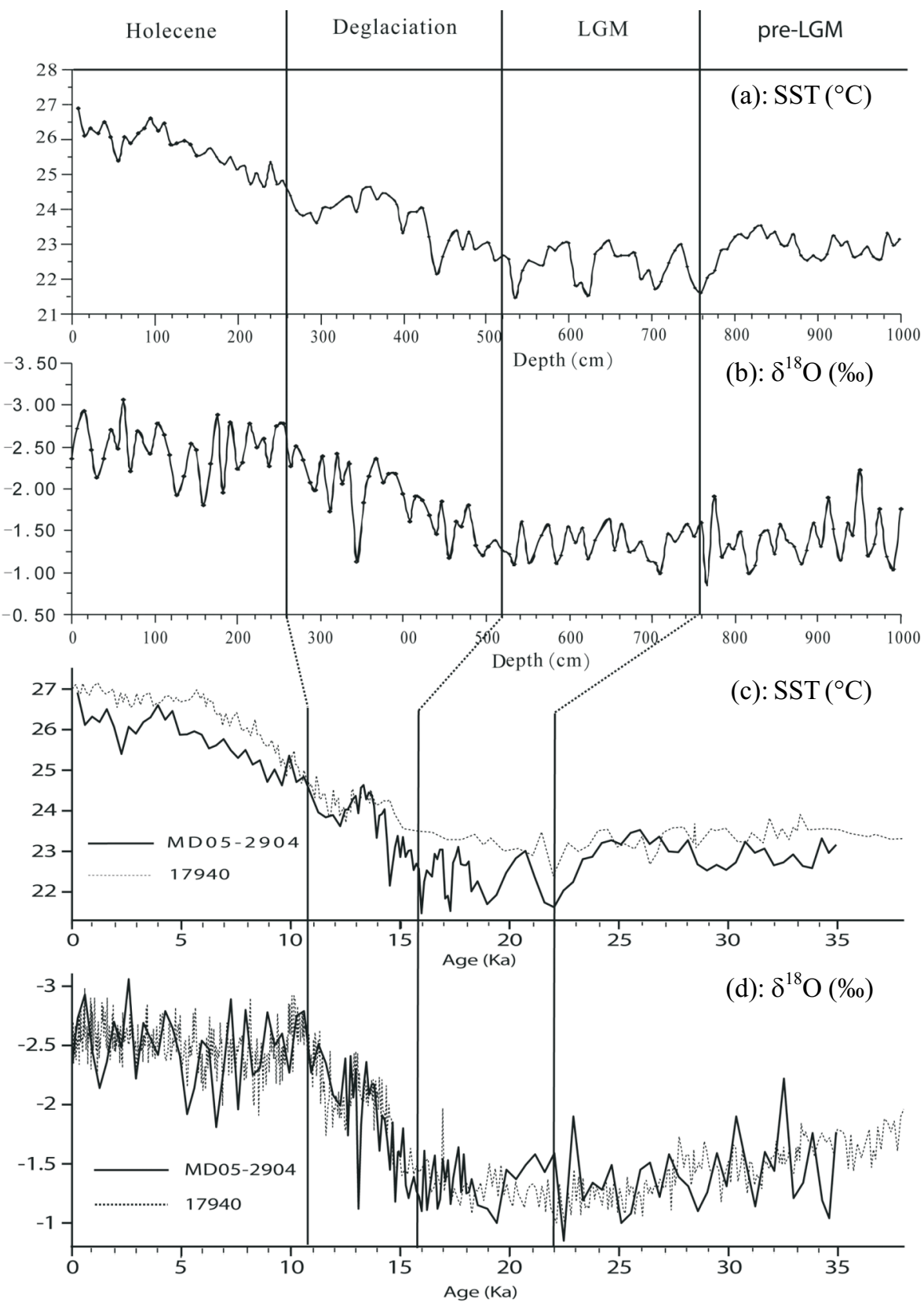

Fig. 2. $\mathrm{U}_{37}^{\mathrm{K}^{\prime}} \mathrm{SST}(\mathrm{a})$ and $\delta^{18} \mathrm{O}$ (b) of planktonic foraminifera Globigerinoides ruber for core MD05-2904 plotted against depth (cm); The comparison of $\mathrm{U}_{37}^{\mathrm{K}^{\prime}} \mathrm{SST}$ records of MD05-2904 (c, solid line) and 17940 (c, dashed line), and the comparison of the $\delta^{18} \mathrm{O}$ records of MD05-2904 (d, solid line) and 17940 (d, dashed line), plotted on age scales. 
that for the LGM. The average glacial and Holocene values and the glacial-interglacial difference of this $\delta^{18} \mathrm{O}$ record are similar to those found in the Globigerinoides ruber $\delta^{18} \mathrm{O}$ record in core 17940 (Wang et al. 1999a). However, the MD05-2904 $\delta^{18} \mathrm{O}$ record shows larger short-term variations, which are partly the result of using both morphotypes of Globigerinoides ruber for $\delta^{18} \mathrm{O}$ measurements (Steinke et al. 2005). The glacial-interglacial trend in our record is also similar to those found in the Globigerinoides sacculifer $\delta^{18} \mathrm{O}$ record in cores 90 - 36, SO50-31 KL and MD972146 (Huang et al. 1997a, b; Lin et al. 2006), all from the northern SCS. Millennial-scale $\delta^{18} \mathrm{O}$ oscillations reveal higher amplitude during the Holocene in both the MD05-2904 and 17940 records, but these oscillations were more pronounced in MIS 3 - 4 in core MD972146 (Lin et al. 2006). The records for cores $90-36$ and SO50-31KL were of lower resolution, so millennial scale $\delta^{18} \mathrm{O}$ oscillations were not well recorded in these cores. Since the $\mathrm{U}_{37}^{\mathrm{K}^{\prime}}$ record (Fig. 2a) for core MD05-2904 shows relatively stable SST for the Holocene, the large $\delta^{18} \mathrm{O}$ oscillations during the Holocene most likely reflect large and frequent sea surface salinity changes, probably related to summer monsoon variations (Wang et al. 1999a, b).

\subsection{Sea Surface Temperature Record}

The $\mathrm{U}_{37}^{\mathrm{K}} \mathrm{SST}$ record of MD05-2904 (Fig. 2a) calculated using the SCS calibration equation $\left(\mathrm{U}_{37}^{\mathrm{K}^{\prime}}=0.031 \mathrm{~T}+0.092\right)$ (Pelejero and Grimalt 1997) ranges from $21^{\circ} \mathrm{C}$ to $26.9^{\circ} \mathrm{C}$, but most of the data fall within $21.6^{\circ} \mathrm{C}$ and $26.9^{\circ} \mathrm{C}$. The average SST for the pre-LGM interval was $22.9^{\circ} \mathrm{C}$, which was higher than the average SST $\left(22.3^{\circ} \mathrm{C}\right)$ for the LGM by $0.6^{\circ} \mathrm{C}$. SST during the deglaciation $(520$ to $260 \mathrm{~cm}$ ) interval was punctuated by two cold reversals centered around 440 and $295 \mathrm{~cm}$. SST continued to increase during the early Holocene $(260-120 \mathrm{~cm})$, but fluctuated around an average value of $26.5^{\circ} \mathrm{C}$ during the late Holocene (the top $120 \mathrm{~cm}$ ). The average SST for the late Holocene was $26.7^{\circ} \mathrm{C}$, hence the SST difference between the LGM and the late Holocene is $4.4^{\circ} \mathrm{C}$. The core top SST value $\left(26.7^{\circ} \mathrm{C}\right)$ is only slightly lower than the annual SST for this site $\left(27^{\circ} \mathrm{C}\right)$, indicating that the $\mathrm{U}_{37}^{\mathrm{K}^{\prime}}$ index records annual SST for the SCS. There were a few millennial scale SST oscillations ( 1 to $1.5^{\circ} \mathrm{C}$ ) during the LGM, but Holocene SST variations were smaller, in contrast to the larger planktonic $\delta^{18} \mathrm{O}$ variations during the Holocene (Fig. 2b).

Due to the lack of a well-constrained age model for this core, only preliminary comparison of this record with those for cores from the northern SCS and other regions is warranted. The LGM-Holocene SST difference $\left(4-5^{\circ} \mathrm{C}\right)$ for this core is consistent with published results for cores from the northern SCS, such as those for cores 17960 (Pelejero et al. 1999a) and SO50-31KL (Huang et al. 1997a). The absolute
SST values of core MD05-2904 for both the glacial and the Holocene are similar to those of core SO50-31KL, but are slightly lower than those of core 17940. These small differences are likely caused by spatial SST variations of the northern SCS and/or by the systematic laboratory errors in the measurements of the $\mathrm{U}_{37}^{\mathrm{K}^{\prime}}$ index. For core MD05-2904, the average SST during the LGM was the lowest, a feature that was observed in several cores from the northern SCS (Huang et al. 1997a; Pelejero et al. 1999a). On the other hand, a high resolution record from the southwestern SCS (MD972151) showed that the SST minimum occurred near the Heinrich event 1 (H1) (Zhao et al. 2006a), a feature that has been observed in several cores from the Atlantic (Mix et al. 1986; Zhao et al. 2000). As a preliminary attempt, we would correlate the low SST event at $440 \mathrm{~cm}$ to the Oldest Dryas in Europe or the $\mathrm{H} 1$ in the North Atlantic Ocean, the SST warming at 400 to $340 \mathrm{~cm}$ to the Bølling/Allerød and IS1 warm event, and the low SST centered around $290 \mathrm{~cm}$ to the Younger Dryas. These tentative assignments need to be confirmed by ${ }^{14} \mathrm{C}$ dating of this core. Finally, the MD052904 record also shows that SST continued to increase during the early Holocene and approached coretop values only during the mid-Holocene, and this delayed warming during the early Holocene was also revealed in most SCS records (Huang et al. 1997a, b; Pelejero et al. 1999a; Wang et al. 1999a; Steinke et al. 2001; Kienast et al. 2001b, 2003; Zhao et al. 2006a), as also summarized by Shintani et al. (2008).

The MD05-2904 record provides additional evidence that the northern SCS cooling during the glacial was larger than those for the open Pacific Ocean at similar latitudes revealed by the alkenone (Ohkouchi et al. 1994) and the $\mathrm{Mg} / \mathrm{Ca}$ (Lea et al. 2000) methods. The enhanced glacial cooling of the SCS has been suggested to be caused by the regional intensification of the East Asian winter monsoon and by the influences of the cool coastal current (Huang et al. 1997a; Wang et al. 1999a). The continued warming trend during the early Holocene in this core has been observed in both the southern and northern SCS and in other parts of the North Pacific (Kiefer and Kienast 2005), but the mechanism for such a trend is not well understood. For the SCS, one possible mechanism is the influence of sea-level changes (Pelejero et al. 1999a, b; Wang et al. 1999a; Zhao et al. 2006a). For example, the close parallelism between the MD972151 SST from the southern SCS and sea-level curves over the last $14.5 \mathrm{kyr}$ was cited as evidence that sea-level rise had a direct and important impact on the SCS SST increase (Zhao et al. 2006a). Both SST and sea-level continued to rise till $7 \mathrm{ka}$. Thus, with rising sea-level, the various gateways between the SCS and the surrounding seas and oceans opened up successively, allowing more entrance of the Indo-Pacific tropical waters to influence the SCS SST. The slow warming of the northern SCS was also recorded in core MD972146 (Shintani et al. 
2008), and it was proposed that this was caused by a stronger winter monsoon during the early Holocene than during the mid-Holocene.

\subsection{Biomarker Content Records and Phytoplankton Productivity Changes}

The content for all biomarkers reveal large changes dur- ing the glacial to Holocene transition. $\mathrm{C}_{37}$-alkenone content (Fig. 3a) varies by a factor of 56, from $22 \mathrm{ng} \mathrm{g}^{-1}$ (at $111 \mathrm{~cm}$ ) to $1243 \mathrm{ng} \mathrm{g}^{-1}$ (at $959 \mathrm{~cm}$ ). The highest values are found near the bottom of the core analyzed so far. This record is also characterized by many millennial scale oscillations. Overall, the alkenone content record shows a decreasing trend from the glacial to the Holocene. Of the four intervals identified for this core, alkenone content is the highest for the early

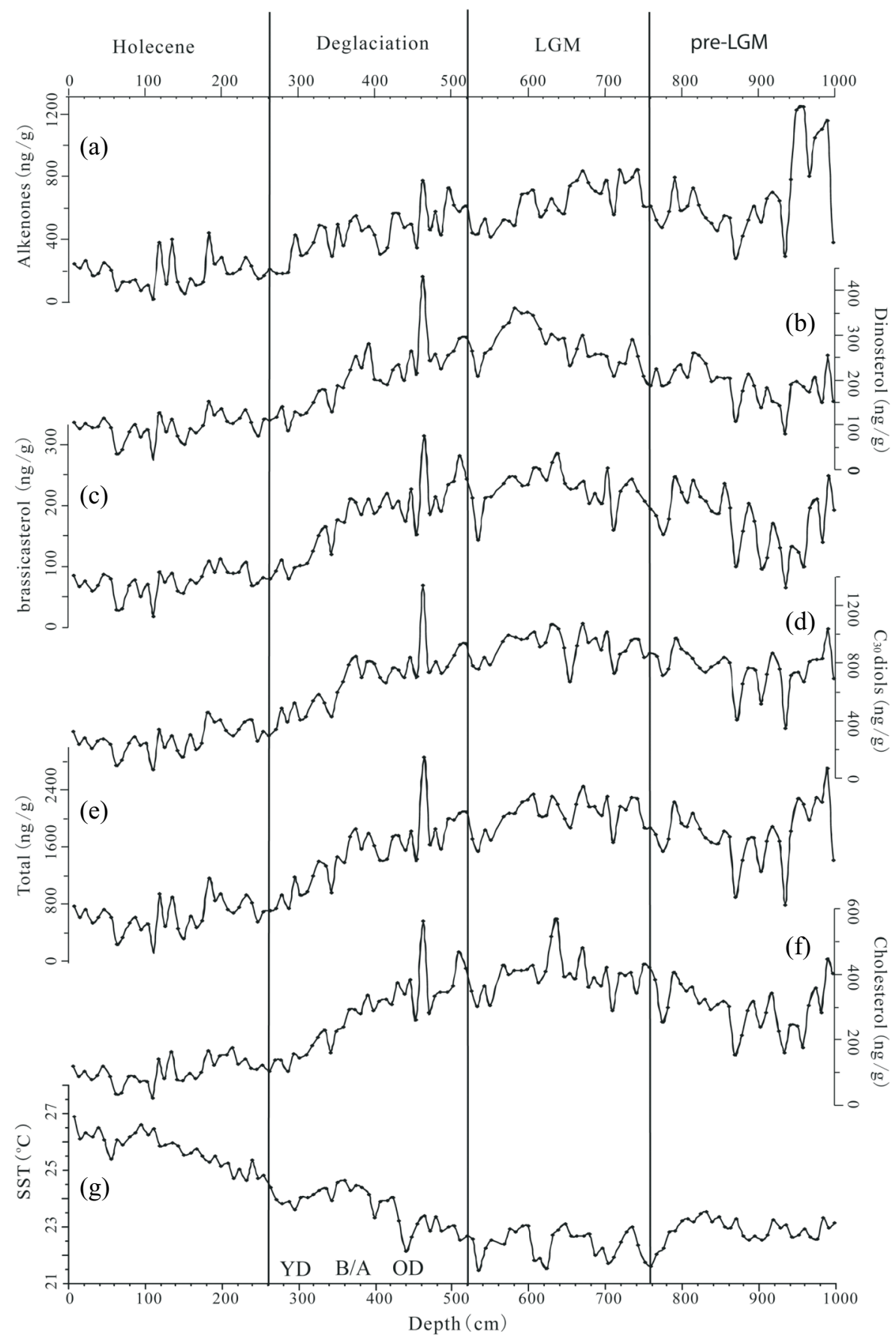

Fig. 3. Biomarker content and $\mathrm{U}_{37}^{\mathrm{K}} \mathrm{SST}\left({ }^{\circ} \mathrm{C}\right)$ for core MD05-2904 plotted against depth (cm). (a) Content of $\mathrm{C}_{37}$-alkenones (ng g $\left.{ }^{-1}\right)$; (b) Content of dinosterol (ng g ${ }^{-1}$ ); (c) Content of brassicasterol ( $\mathrm{ng} \mathrm{g}^{-1}$ ); (d) Content of $\mathrm{C}_{30}$-diols ( $\mathrm{ng} \mathrm{g}^{-1}$ ); (e) The total contents of $\mathrm{C}_{37}$ alkenones, dinosterol, brassicasterol and $\mathrm{C}_{30}$ diols; (f) Content of sterol $\left(\mathrm{ng} \mathrm{g}^{-1}\right)$; ( $(\mathrm{g}) \mathrm{U}_{37}^{\mathrm{K}^{\prime}} \mathrm{SST}\left({ }^{\circ} \mathrm{C}\right)$. YD, B/D, and OD indicate the intervals preliminarily assigned to the age of the Younger Dryas, Bølling/Allerød, and Oldest Dryas, respectively. 
part of the pre-LGM and for the LGM, and the lowest for the Holocene. The alkenone content range and the overall glacial-interglacial pattern for this core are in general agreement with previously published results for the SCS (Huang et al. 1997b; Pelejero et al. 1999b; Kienast et al. 2001a; Zhao et al. 2006a).

The contents of dinosterol, brassicasterol, $\mathrm{C}_{30}$-diols and cholesterol are reported for the first time from the SCS. Dinosterol content (Fig. 3b) shows a range of $22 \mathrm{ng} \mathrm{g}^{-1}$ (at $111 \mathrm{~cm}$ ) to $431 \mathrm{ng} \mathrm{g}^{-1}$ (at $463 \mathrm{~cm}$ ). However, the $463 \mathrm{~cm}$ value is exceptionally high during a decreasing trend. If this exception is excluded, the highest value is $362 \mathrm{ng} \mathrm{g}^{-1}$ at $583 \mathrm{~cm}$. Thus, the dinosterol content varies by a factor of 16 . Brassicasterol content (Fig. 3c) shows a range of $17 \mathrm{ng} \mathrm{g}^{-1}$ (at $111 \mathrm{~cm}$ ) to $285 \mathrm{ng} \mathrm{g}^{-1}$ (at $639 \mathrm{~cm}$ ), excluding the point at the $463 \mathrm{~cm}$. Thus, the brassicasterol content varies by a factor of $17 . \mathrm{C}_{30}$-diol content (Fig. 3d) shows a range of $56 \mathrm{ng} \mathrm{g}^{-1}$ (at $111 \mathrm{~cm}$ ) to $1079 \mathrm{ng} \mathrm{g}^{-1}$ (at $671 \mathrm{~cm}$ ) and, with the point at $463 \mathrm{~cm}$ excluded, varies by a factor of 19 . Cholesterol content (Fig. 3f) shows a range of $21 \mathrm{ng} \mathrm{g}^{-1}$ (at $111 \mathrm{~cm}$ ) to $567 \mathrm{ng} \mathrm{g}^{-1}$ (at $639 \mathrm{~cm}$ ) and varies by a factor of 17 . The downcore variations of the contents of dinosterol, brassicasterol, $\mathrm{C}_{30}$-diol and cholesterol are very similar. They all increased from the pre-LGM period toward the LGM, reached maximum average values during the LGM, and began a decreasing trend during the deglaciation interval, except for the one-point high value at $463 \mathrm{~cm}$. The values for the Holocene were the lowest.

The contents of alkenones, dinosterol, brassicasterol and $\mathrm{C}_{30}$-diol are used as productivity proxies for haptophytes, dinoflagellates, diatoms, and eustigmatophytes, respectively. The above trends indicate that, for core MD05-2904, productivity for these phytoplankton groups changed in similar patterns during the last glacial and Holocene: high values during the glacial and LGM, beginning to decrease during the deglaciation, and lower values for the Holocene. To a first degree approximation, the total content values of alkenones, dinosterol, brassicasterol and $\mathrm{C}_{30}$-diols (total, Fig. 3e) can be used as a proxy for total phytoplankton productivity. This proxy also reveals a similar glacial-interglacial trend: high values during the glacial and LGM, beginning to decrease during the deglaciation, and lower values for the Holocene. The content of cholesterol is used as a proxy for the biomass of zooplankton, and it also reveals a pattern similar to the phytoplankton biomarker contents during the last glacial and Holocene, indicating that zooplankton biomass was controlled by primary productivity. An X-Y plot of the total phytoplankton biomarker content versus the cholesterol content reveals a very good correlation $\left(r^{2}=0.86\right.$, Fig. $\left.4 a\right)$.

The clear glacial-interglacial pattern of the biomarker proxies can be further evaluated by simple $\mathrm{X}-\mathrm{Y}$ plots of the content of biomarkers versus SST. The X-Y plot of $\mathrm{C}_{37^{-}}$ alkenone content versus SST reveals a moderate correlation with an $\mathrm{r}^{2}$ of 0.47 (Fig. 4b). In contrast, an X-Y plot of
$\mathrm{C}_{37}$-alkenone content versus SST of a longer record from the southern SCS (MD972151) did not reveal any significant correlation (Zhao et al. 2006a). X-Y plots of the content of dinosterol, brassicasterol, $\mathrm{C}_{30}$ diol versus SST all reveal relatively good linear relationships with $\mathrm{r}^{2}$ values of 0.51 (Fig. 4c), 0.55 (Fig. 4d), and 0.67 (Fig. 4e), respectively. The X-Y plot of the total productivity proxy and SST has an $r^{2}$ value of 0.66 (Fig. 4f).

The glacial-interglacial productivity pattern for core MD05-2904 revealed by these biomarker proxies is generally in agreement with those by other proxies for the northern SCS. For example, the content of TOC (Huang et al. 1997a, b) and chlorins (Higginson et al. 2003) showed higher total productivity during the glacials, while the contents of opal (Lin et al. 1999) and alkenones (Huang et al. 1997a, b; Kienast et al. 2001a) revealed higher productivity for diatom and haptophyte productivity during the glacials. On the other hand, glacial-intetglacial productivity change for the southern SCS revealed different patterns. Opal content record for ODP 1143 indicated lower diatom productivity for the southern SCS during the glacial (Wang and Li 2003). Alkenone content from the southern SCS revealed a decreasing trend during the last glacial period extending beyond the LGM and into the Holocene, before the productivity increased in the Holocene (Pelejero et al. 1999b; Kienast et al. 2001a; Zhao et al. 2006a).

The productivity trends for the northern SCS revealed by the different proxies suggest similar fertilization mechanisms for all phytoplankton groups during the glacial. Both marine and terrestrial records suggest a stronger winter monsoon during the glacial (Wang et al. 1999a; Porter 2001; Wang et al. 2001), which would be the common mechanism for increased productivity. For the modern environment, productivity for the northern SCS is the highest during the winter (Liu et al. 2002), when stronger monsoon results in a deeper mixed layer and strengthened upwelling/ eddy circulation. Glacial increase in both winter monsoon strength and duration would intensify upwelling and mixing (Huang et al. 1997b) to bring more nutrients to the surface, accounting for most of the productivity increases for the northern SCS. However, the additional fertilization effect of the expected increase in dust input to the SCS has not been thoroughly investigated. In addition, the role of riverine materials during the glacial is not clear either. The drier climate would reduce river-transported nutrient to the northern SCS, but the drop in sea-level increased the input of terrestrial materials to the continental slope region, (Wang et al. 1999a; Pelejero 2003) where most of the paleo-records have been obtained so far.

\subsection{Biomarker Percentage and Phytoplankton Community Structure Changes}

As indicated in section 3.3, qualitative comparison of 

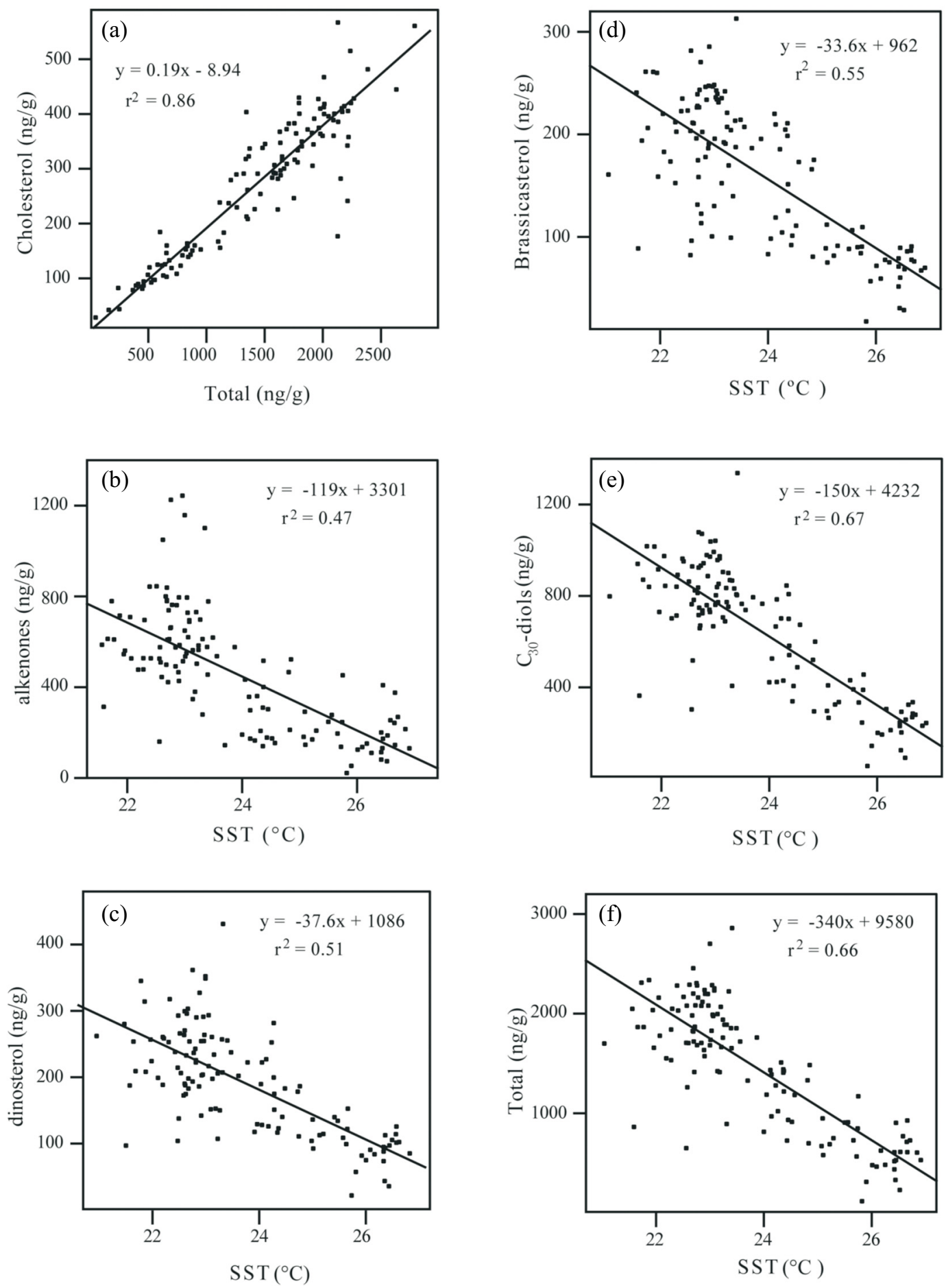

Fig. 4. X-Y plots. (a) Content of cholesterol versus the total content of $\mathrm{C}_{37}$-alkenones, dinosterol, brassicasterol, and $\mathrm{C}_{30}$-diols. (b) Content of $\mathrm{C}_{37}$-alkenones versus $\mathrm{U}_{37}^{\mathrm{K}} \mathrm{SST}$. (c) Content of dinosterol versus $\mathrm{U}_{37}^{\mathrm{K}} \mathrm{SST}$. (d) Content of brassicasterol versus $\mathrm{U}_{37}^{\mathrm{K}} \mathrm{SST}$. (e) Content of $\mathrm{C}_{30}$-diols versus $\mathrm{U}_{37}^{\mathrm{K}} \mathrm{SST}$. (f) The total contents of $\mathrm{C}_{37}$-alkenones, dinosterol, brassicasterol, and $\mathrm{C}_{30}$-diols versus $\mathrm{U}_{37}^{\mathrm{K}} \mathrm{SST}$.

the individual biomarker contents (Fig. 3) suggests similar glacial-interglacial change patterns. This could imply that the phytoplankton community structure remained stable although individual phytoplankton productivity all decreased significantly from the glacial to the Holocene. A more quantitative way to evaluate community structure changes is the normalized biomarker content (Werne et al. 2000; Higginson and Altabet 2004). Plotted in Fig. 5 are the percentages of the four biomarkers by normalization of individual biomarker content to their total amount. At least semi-quantitatively, these plots reveal relative contributions of these phytoplanktons to the total productivity (Werne et al. 2000; 


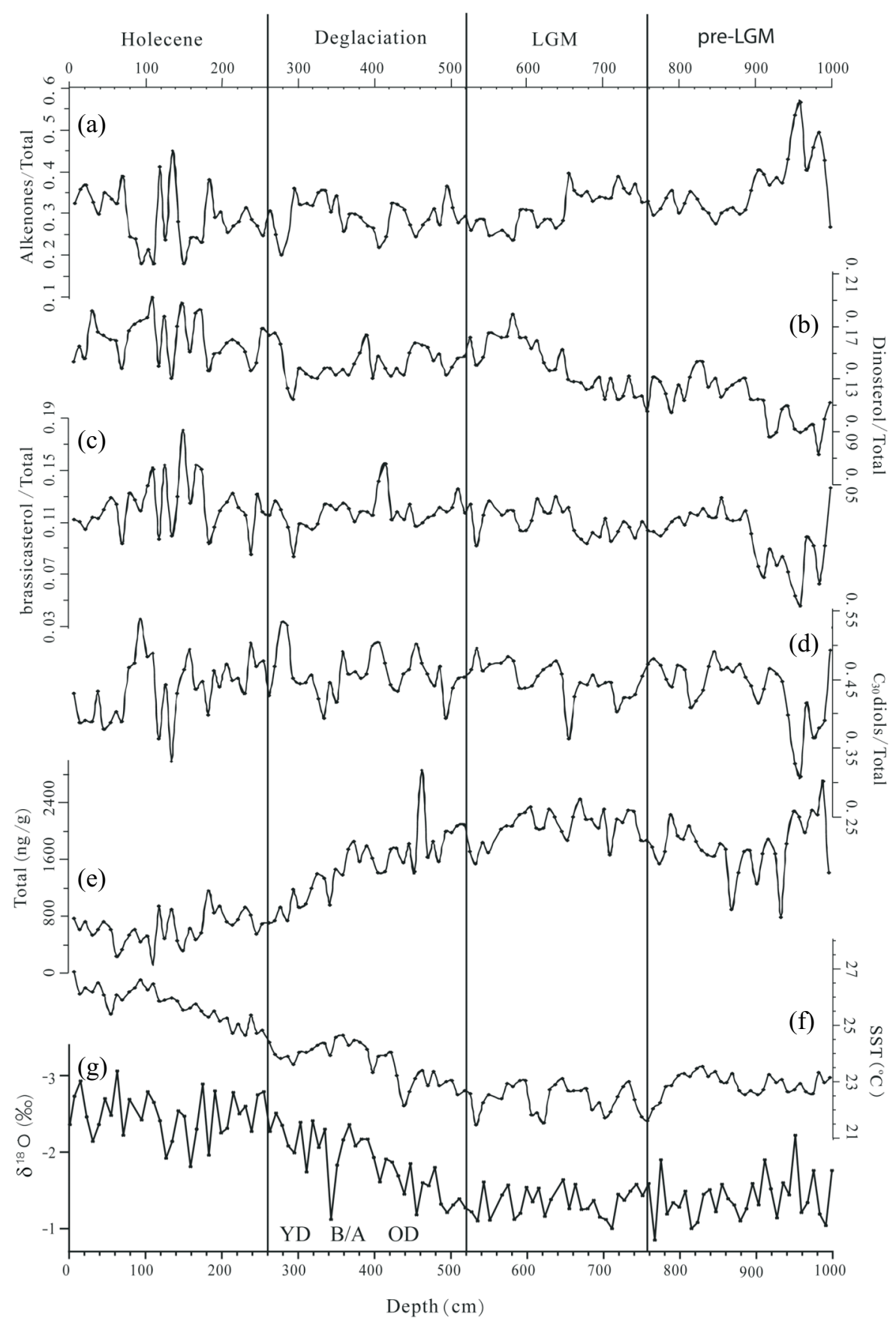

Fig. 5. Biomarker content percentage (normalized to the total content) for core MD05-2904 plotted against depth (cm). (a) $\mathrm{C}_{37}$-alkenones/total; (b) dinosterol/toal; (c) brassicasterol/total; (d) $\mathrm{C}_{30}$-diols/total; (e) total; (f) $\mathrm{U}_{37}^{\mathrm{K}^{\mathrm{K}}} \mathrm{SST}$; (g) $\delta^{18} \mathrm{O}$ of planktonic foraminifera Globigerinoides ruber. YD, $\mathrm{B} / \mathrm{D}$, and OD indicate the intervals preliminarily assigned to the age of the Younger Dryas, Bølling/Allerød, and Oldest Dryas, respectively.

Higginson and Altabet 2004). Several features are revealed by this approach, the most obvious is that the community structure underwent significant changes during the last glacial and Holocene. Based on the biomarker face values, the percentage of haptophytes (Fig. 5a) was as high as $55 \%$ (pre-LGM) and as low as $15 \%$ (mid-Holocene); the range was $19 \%$ (Holocene) and 7\% (pre-LGM) for dinoflagellates (Fig. 5b), 17\% (Holocene) and 5\% (pre-LGM) for diatoms (Fig. 5c), and 50\% (deglaciation and Holocene) to 30\% (pre-LGM) for eustigamatophytes (Fig. 5d). Overall, these records show that smaller phytoplanktons such as haptophytes and eustigmatophytes dominate the community structure for this site. In contrast to the total productivity index (Fig. 5e), the normalized biomarker contents did not reveal a glacial-interglacial trend in community structure changes, but certain short intervals exhibited some major changes. For the early part of the pre-LGM period (1000 to $950 \mathrm{~cm}$ ) when the total productivity was high, haptophyte 
contribution was the highest. From 900 to $600 \mathrm{~cm}$ (within the LGM) when the total productivity was showing an increasing trend, the haptophyte contribution to total productivity showed small decreases while the contribution from dinoflagellates, and to some degree from diatoms, increased slightly. However, during the deglaciation to the Holocene transition when the total productivity decreased significantly, the relative productivity of these groups did not experience any significant changes, although there were small oscillations. On the other hand, the community structure during the mid-Holocene revealed large oscillations, even though the climate expressed by SST (Fig. 5f) was relatively stable. Overall, each biomarker's average values for the four intervals (pre-LGM, LGM, deglaciation and the Holocene) are quite similar, indicating the community structure over orbital timescale (thousands of years) remained relatively stable during the last glacial and Holocene. Instead, millennial to sub-millennial scale changes were frequent during the mid-Holocene when the $\delta^{18} \mathrm{O}$ record (Fig. 5g) also shows large oscillations, indicating these changes were related to summer monsoon variations.

Thus, the relatively stable community structure for MD05-2904 from the northern SCS is similar to records obtained from the Arabian Sea (Schubert et al. 1998) and the equatorial Indian Ocean (Schulte and Bard 2003). In other regions, the community structure from the deglaciation to the Holocene transition revealed major changes. In the Cariaco Basin, the biomarker record revealed a shift from diatom-dominated community during the Younger Dryas cold period to a haptophyte-dominated community during the warm Holocene (Werne et al. 2000). Community structure in the Sea of Okhotsk shifted the opposite way, from a haptophyte-domination during the deglaciation to diatomdomination during the Holocene (Seki et al. 2004). These different trends reflected community structure responses to different climate and nutrient-input changes for these regions. For core MD05-2904, the increased fertilization during the last glacial period increased total productivity but did not cause a major shift in community structure, indicating that macro- and micro-nutrient composition during the glacial could be similar to that of today. This study and results from the Arabian Sea and the tropical Indian Ocean indicate that community structure could remain stable in these tropical regions even under different climate conditions. Part of the reason is that these warm regions are normally oligiotrophic and the phytoplankton community is dominated by smaller phytoplanktons, such as coccolithophorids. However in the Arabian Sea under upwelling conditions, diatoms and dinoflagellates are very important (Schubert et al. 1998).

One notable feature of the MD05-2904 record is the short-term, large amplitude oscillations in community structure, such as those that occurred during pre-LGM (1000 and $950 \mathrm{~cm})$ and during the mid-Holocene $(180$ to $80 \mathrm{~cm})$. These oscillations, especially the mid-Holocene oscillations, are coeval with large $\delta^{18} \mathrm{O}$ fluctuations (Fig. $5 \mathrm{~g}$ ). Since we have argued that these mid-Holocene $\delta^{18} \mathrm{O}$ fluctuations mainly reflected summer monsoon changes, the biomarker results could imply that community structure in the SCS is more responsive to summer monsoon influence, probably as a result of changing nutrient supplies from rivers. More such reconstructions from the SCS, especially from the southern SCS, which is more influenced by summer monsoon forcing (Liu et al. 2002; Wang and Li 2003) and thus could exhibit more community structure change, would help in our understanding of mechanisms of community structure changes in the SCS at millennial and sub-millennial timescales.

\section{CONCLUSIONS}

High resolution abundance records of a suite of marine biomarkers have been generated for the first time in the northern SCS (core MD05-2904). $\mathrm{C}_{37}$-alkenones, dinosterol, brassicasterol, and $\mathrm{C}_{30}$-diols are used as productivity proxies for haptophytes, dinoflagellates, diatoms, and eustigmatophytes, respectively. Their content records reveal that productivities for these phytoplankton groups vary similarly during the last glacial and Holocene, with much higher values during the LGM compared with lower values during the Holocene. Total productivity was also higher during the GM, as was zooplankton biomass revealed by cholesterol content. Surprisingly, the community structure expressed by biomarker percentages stayed relatively stable during the glacial-to-Holocene transition. These results imply that the increased nutrient supply to the northern SCS caused by the stronger winter monsoon during the glacial enhanced productivity of all phytoplankton groups proportionally. On the other hand, short-term and large amplitude oscillations in community structure were observed during the pre-LGM period and in the mid-Holocene, when large monsoon oscillations occurred as indicated by the planktonic foraminiferal oxygen isotope record for this core. It is inferred that the SCS phytoplankton community structure at millennial and sub-millennial timescales could be more responsive to summer monsoon forcing, which can be verified by more such biomarker-based reconstruction, especially from the southern SCS.

Acknowledgements We thank X. Cheng and H. Ren for assistance in isotope measurements, and the reviewers for their helpful suggestions to improve the manuscript. This study was supported by the National Natural Science Foundation of China (Grant No. 40676032, 40776029, 40403012, and 40621063).

\section{REFERENCES}

Higginson, M. J. and M. A. Altabet, 2004: Initial test of the 
silicic acid leakage hypothesis using sedimentary biomarkers. Geophys. Res. Lett., 31, L18303, doi:10.1029/ 2004GL020511.

Higginson, M. J., J. R. Maxwell, and M. A. Altabet, 2003: Nitrogen isotope and chlorin paleoproductivity records from the Northern South China Sea: Remote vs. local forcing of millennial- and orbital-scale variability. Mar. Geol., 201, 223-250.

Hinrichs, K. U., R. R. Schneider, P. J. Mueller, and J. Rullkoetter, 1999: A biomarker perspective on paleoproductivity variations in two late Quaternary sediment sections from the Southeast Atlantic Ocean. Org. Geochem., 30, 341-366.

Huang, C. Y., P. M. Liew, M. X. Zhao, T. C. Chang, C. M. Kuo, M. T. Chen, C. H. Wang, and L. F. Zheng, 1997a: Deep sea and lake records of the Southeast Asian paleomonsoons for the last 25 thousand years. Earth Planet. Sci. Lett., 146, 59-72.

Huang, C. Y., S. F. Wu, M. X. Zhao, M. T. Chen, C. H. Wang, X. Tu, and P. B. Yuan, 1997b: Surface ocean and monsoon climate variability in the South China Sea since the last glaciation. Mar. Micropaleontol., 32, 71-94.

Kiefer, T. and M. Kienast, 2005: Patterns of deglacial warming in the Pacific Ocean: A review with emphasis on the time interval of Heinrich event 1. Quat. Sci. Rev., 24, 1063-1081.

Kienast, M., S. E. Calvert, C. Pelejero, and J. O. Grimalt, 2001a: A critical review of marine sedimentary $\delta^{13} \mathrm{C}_{\text {org }}{ }^{-}$ $p \mathrm{CO}_{2}$ estimates: New palaeorecords from the South China Sea and a revisit of other low-latitude $\delta^{13} \mathrm{C}_{\text {org }}-p \mathrm{CO}_{2}$ records. Global Biogeochem. Cycles, 15, 113-127.

Kienast, M., S. Steinke, K. Stattegger, and S. E. Calvert, 2001b: Synchronous tropical South China Sea SST change and Greenland warming during deglaciation. Science, 291, 2132-2134.

Kienast, M., T. J. J. Hanebuth, C. Pelejero, and S. Steinke, 2003: Synchroneity of meltwater pulse $1 \mathrm{a}$ and the Bolling warming: New evidence from the South China Sea. Geology, 31, 67-70.

Lea, D. W., D. K. Pak, and H. J. Spero, 2000: Climate impact of late quaternary equatorial Pacific sea surface temperature variations. Science, 289, 1719-1724.

Lin, D. C., C. H. Liu, T. H. Fang, C. H. Tsai, M. Murayama, and M. T. Chen, 2006: Millennial-scale changes in terrestrial sediment input and Holocene surface hydrography in the northern South China Sea (IMAGES MD972146). Palaeogeogr. Palaeoclimatol. Palaeoecol., 236, 56-73.

Lin, H. L., C. T. Lai, H. C. Ting, L. J. Wang, M. Sarnthein, and J. J. Hung, 1999: Late Pleistocene nutrients and sea surface productivity in the South China Sea: A record of teleconnections with northern hemisphere events. Mar. Geol., 156, 197-210.

Liu, K. K., S. Y. Chao, P. T. Shaw, G. C. Gong, C. C. Chen, and T. Y. Tang, 2002: Monsoon-forced chlorophyll distribution and primary production in the South China Sea: Observations and a numerical study. Deep-Sea Res. I, 49, $1387-1412$.
Menzel, D., P. F. van Bergen, S. Schouten, and J. S. Sinninghe Damste, 2003: Reconstruction of changes in export productivity during Pliocene sapropel deposition: A biomarker approach. Palaeogeogr. Palaeoclimatol. Palaeoecol., 190, 273-287.

Mix, A. C., W. F. Ruddiman, and A. McIntyre, 1986: Late Quaternary paleoceanography of the tropical Atlantic, 1: Spatial variability of annual mean sea-surface temperatures, 9-20,000 years B.P. Paleoceanography, 1, 43-66.

Ohkouchi, N., K. Kawamura, T. Nakamura, and A. Taira, 1994: Small changes in the sea-surface temperature during the last 20,000 years - Molecular evidence from the western tropical Pacific. Geophys. Res. Lett., 21, 2207-2210.

Pelejero, C., 2003: Terrigenous $n$-alkane input in the South China Sea: High-resolution records and surface sediments. Chem. Geol., 200, 89-103.

Pelejero, C. and J. O. Grimalt, 1997: The correlation between the $\mathrm{U}^{\mathrm{K}}{ }_{37}$ index and sea surface temperatures in the warm boundary: The South China Sea. Geochim. Cosmochim. Acta, 61, 4789-4797.

Pelejero, C., J. O. Grimalt, S. Heilig, M. Kienast, and L. J. Wang, 1999a: High-resolution $\mathrm{U}^{\mathrm{K}}{ }_{37}$ temperature reconstructions in the South China Sea over the past 220 kyr. Paleoceanography, 14, 224-231.

Pelejero, C., J. O. Grimalt, M. Sarnthein, L. J. Wang, and J. A. Flores, 1999b: Molecular biomarker record of sea surface temperature and climatic change in the South China Sea during the last 140,000 years. Mar. Geol., 156, 109-121.

Porter, S. C., 2001: Chinese loess record of monsoon climate during the last glacial-interglacial cycle. Earth-Sci. Rev., 54, 115-128.

Schubert, C. J., J. Villanueva, S. E. Calvert, G. L. Cowie, U. von Rad, H. Schultz, U. Berner, and H. Erlenkeuser, 1998: Stable phytoplankton community structure in the Arabian Sea over the past 200,000 years. Nature, 394, 563-566.

Schulte, S. and E. Bard, 2003: Past changes in biologically mediated dissolution of calcite above the chemical lysocline recorded in Indian Ocean sediments. Quat. Sci. Rev., 22, 1757-1770.

Seki, O., M. Ikehara, K. Kawamura, T. Nakatsuka, K. Ohnishi, M. Wakatsuchi, H. Narita, and T. Sakamoto, 2004: Reconstruction of paleoproductivity in the Sea of Okhotsk over the last 30 kyr. Paleoceanography, 19, PA1016, doi: 10.1029/2002PA000808.

Shintani, T., M. Yamamoto, and M. T. Chen, 2008: Slow warming of the northern South China Sea during the last deglaciation. Terr. Atmos. Ocean. Sci., 19, 341-346, doi: 10.3319/TAO.2008.19.4.341(IMAGES).

Steinke, S., M. Kienast, U. Pflaumann, M. Weinelt, and K. Stattegger, 2001: A high-resolution sea-surface temperature record from the tropical South China Sea $(16,500$ 3000 yr B.P.). Quat. Res., 55, 352-362.

Steinke, S., H. Y. Chiu, P. S. Yu, C. C. Shen, L. Lowemark, H. S. Mii, and M. T. Chen, 2005: $\mathrm{Mg} / \mathrm{Ca}$ ratios of two Globigerinoides ruber (white) morphotypes: Implications for 
reconstructing past tropical/ subtropical surface water conditions. Geochem. Geophys. Geosyst., 6, doi:10.1029/ $2005 \mathrm{GC} 000926$.

Thunell, R. C., Q. Miao, S. E. Calvert, and T. F. Pedersen, 1992: Glacial-Holocene biogenic sedimentation patterns in the South China Sea: Productivity variations and surface water $p \mathrm{CO}_{2}$. Paleoceanography, 7, 143-162.

Versteegh, G. J. M. and K. A. F. Zonneveld, 2002: Use of selective degradation to separate preservation from productivity. Geology, 30, 615-618.

Wang, L., M. Sarnthein, H. Erlenkeuser, J. Grimalt, P. Grootes, S. Heilig, E. Ivanova, M. Kienast, C. Pelejero, and U. Pflaumann, 1999a: East Asian monsoon climate during the Late Pleistocene: High-resolution sediment records from the South China Sea. Mar. Geol., 156, 245-284.

Wang, L., M. Sarnthein, H. Erlenkeuser, P. M. Grootes, J. O. Grimalt, C. Pelejero, and G. Linck, 1999b: Holocene variations in Asian monsoon moisture: a bidecadal sediment record from the South China Sea. Geophys. Res. Lett., 26, 2889-2892.

Wang, R. J. and J. Li, 2003: Quaternary high-resolution opal record and its paleoproductivity implication at ODP Site 1143, southern South China Sea. Chin. Sci. Bull., 48,
363-367.

Wang, Y. J., H. Cheng, R. L. Edwards, Z. S. An, J. Y. Wu, C. C. Shen, and J. A. Dorale, 2001: A high-resolution absolutedated Late Pleistocene monsoon record from Hulu Cave, China. Science, 294, 2345-2348.

Werne, J. P., D. J. Hollander, T. W. Lyons, and L. C. Peterson, 2000: Climate-induced variations in productivity and planktonic ecosystem structure from the Younger Dryas to Holocene in the Cariaco Basin, Venezuela. Paleoceanography, 15, 19-29.

Zhao, M., G. Eglinton, S. K. Haslett, R. W. Jordan, M. Sarnthein, and Z. H. Zhang, 2000: Marine and terrestrial biomarker records for the last 35,000 years at ODP Site 658C off NW Africa. Org. Geochem., 31, 919-930.

Zhao, M., C. Y. Huang, C. C. Wang, and G. J. Wei, 2006a: A millennial-scale $\mathrm{U}^{\mathrm{K}}{ }_{37}$ sea-surface temperature record from the South China Sea $\left(8^{\circ} \mathrm{N}\right)$ over the last $150 \mathrm{kyr}$ : Monsoon and sea-level influence. Palaeogeogr. Palaeoclimatol. Palaeoecol., 236, 39-55.

Zhao, M., J. L. Mercer, G. Eglinton, M. J. Higginson, and C. Y. Huang, 2006b: Comparative molecular biomarker assessment of phytoplankton paleoproductivity for the last $160 \mathrm{kyr}$ off Cap Blanc, NW Africa. Org. Geochem., 37, 72-97. 